\title{
21. ASPECTS OF THE GEOLOGY OF THE EASTERN CORAL SEA AND THE WESTERN NEW HEBRIDES BASIN
}

\author{
Charles W. Landmesser and James E. Andrews, Department of Oceanography, \\ University of Hawaii, Honolulu, Hawaii \\ and \\ Gordon H. Packham, Department of Geology and Geophysics, University of Sydney, NSW, \\ Australia
}

\begin{abstract}
The submarine geology of the eastern Coral Sea and New Hebrides Basins in the southwest Pacific is characterized by complex bathymetry, comprising numerous geomorphological and structural features related to the tectonic setting of the region near the margin of the India plate. Most of the main structural features of the region appear to be of Eocene age.

Miocene and younger sediments in the eastern Coral Sea are turbidity current deposits on the Coral Sea Abyssal Plain and pelagic biogenic sediments and abyssal clays in other parts of the basin. Eocene and Oligocene sediments are probably biogenic oozes. The oldest sediments of the New Hebrides Basin are mid Eocene to Oligocene biogenic sediments and Miocene abyssal clays. Elevation of various ridges later in the history of the region and the approach of the New Hebrides Ridge have been responsible for the shedding of clastics into the basin.

The major physiographic features of the region are the Louisiade Rise in the eastern Coral Sea, the Rennell Island and East Rennell Island ridges between the Coral Sea and the New Hebrides Basin, the Rennell Trough on the southeast side of the Rennell Island Ridge, and the d'Entrecasteaux Fracture Zone in the New Hebrides Basin. The nature and age of some of these features are ambiguous.

The Louisiade Rise is cut by a fracture system. The rise may be either submerged continental crust or an old spreading ridge in which the crust was thickened during decreased spreading associated with its demise as an active feature. The fracture zone is probably a transform fault (system) related to the opening of the Coral Sea.

The Rennell Island and East Rennell Island ridges may be fragments of the Mesozoic fold belt that margins much of eastern Gondwanaland, or they may be in part or entirely built of island arc volcanics related to the opening of the Coral Sea.

The Rennell Fracture Zone may have been formed during the Coral Sea-New Hebrides Basin development as a transform fault between them, or it could have resulted from the relocation of the India-Pacific plate boundary that formed in the early Oligocene after obduction took place in New Caledonia.
\end{abstract}

\section{INTRODUCTION}

The purpose of this chapter is to review the available data on the highly complex eastern part of the Coral Sea and the western part of the New Hebrides Basin. Unfortunately, the present state of knowledge leaves most of the critical questions of the region unresolved, but it is hoped that this review will highlight the more important problems and stimulate further investigations into the marine geology of the region. Some of the implications of this review are further discussed in the regional synthesis chapter (Packham and Andrews, this volume).

The Coral Sea Basin (Figure 1) is one of several marginal basins in the complex structure of the southwest Pacific. As defined by Wiseman and Ovey (1954), the Basin is bounded by the Queensland Plateau and Australian continental margin on the southwest, by the margin of Papua-New Guinea, the Papuan Plateau and the Louisiade Archipelago on the northwest, and by the Solomon Islands and South Solomon Trench on the north, while a major NNE-SSW trending ridge, the Rennell Ridge of Krause (1967), separates the Coral Sea Basin from the New Hebrides Basin to the east.

The Coral Sea Basin presently forms part of the northeastern margin of the India plate, directly adjacent to the western boundary of the Pacific plate.

In order to more clearly define the structural units of the Coral Sea Basin, a detailed bathymetric chart has 


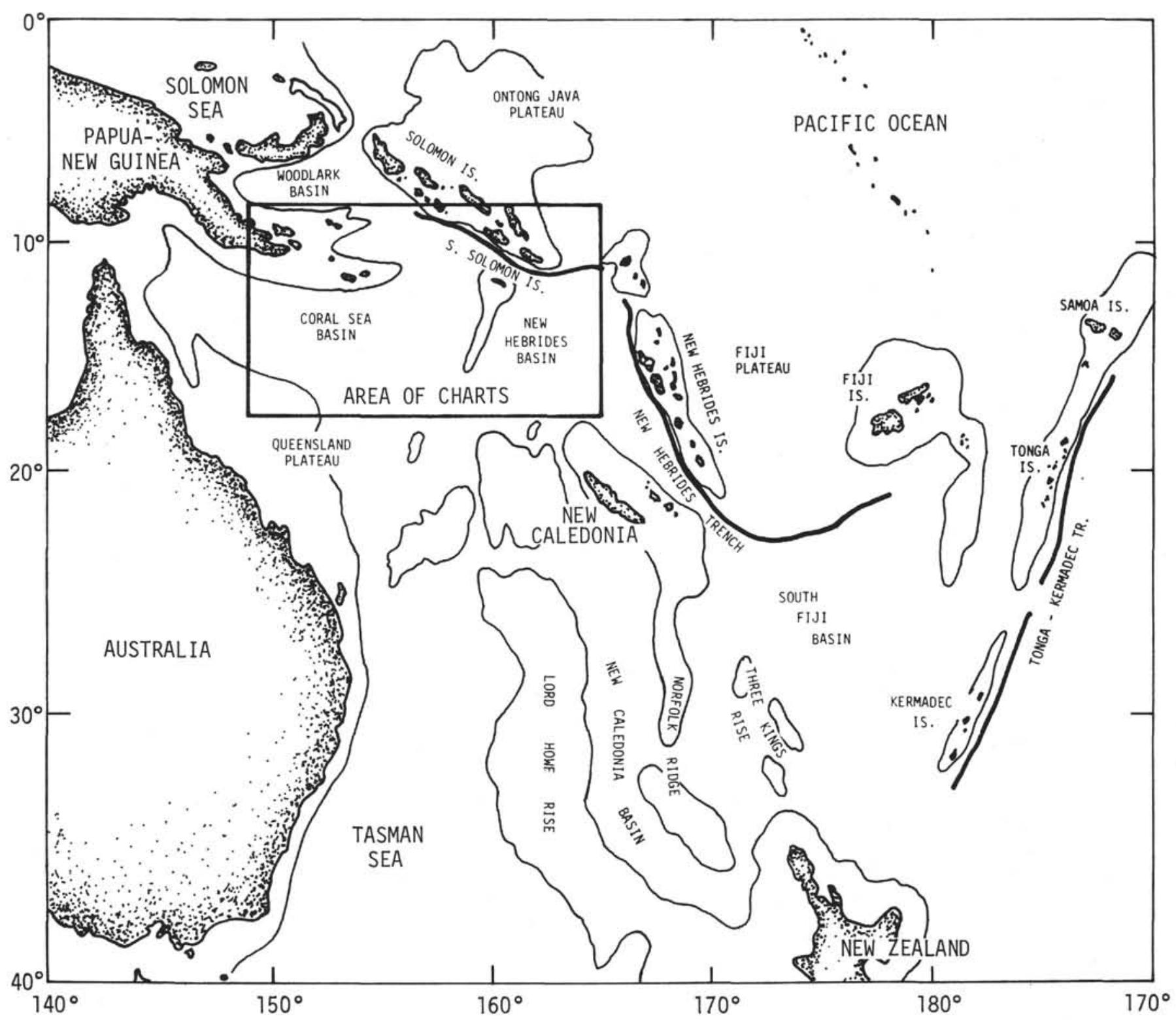

Figure 1. Location of the eastern Coral Sea Basin in the southwest Pacific.

been constructed. Depths are based on a sound velocity of $1500 \mathrm{~m} / \mathrm{sec}$ and are uncorrected for variations. Gardner (1970) has presented a chart of the western Coral Sea, and the chart presented here encompasses the greater part of the eastern Coral Sea.

Bathymetric data utilized include the most recent compilation of soundings by the Hydrographic Office of the Royal Australian Navy on their GEBCO 1:1,000,000 plotting sheet series, bathymetry along tracks of the M/V Taranui, R/V Mahi, and R/V Kana Keoki obtained by the Hawaii Institute of Geophysics, bathymetric data from the NOVA Expedition of Scripps Institution of Oceanography, and bathymetry along tracks of D/V Glomar Challenger during Legs 21 and 30. Seismic profiles used in this work are from Hawaii Institute of Geophysics cruises of the R/V Kana Keoki, $\mathrm{R} / \mathrm{V} \mathrm{Mahi}$, and R/V Vema, and from Legs 21 and 30 of D/V Glomar Challenger.

\section{BATHYMETRY AND PHYSIOGRAPHY}

Bathymetry of the eastern Coral Sea Basin is presented in Chart 1 (in back pocket of volume). Based on these bathymetric contours and several previous studies, a number of physiographic provinces have been defined in the Coral Sea Basin. The location of these features is shown in Figure 2.

The western Coral Sea Basin is dominated by the Coral Sea Abyssal Plain, as previously discussed by Gardner (1970) and Ewing et al. (1970). This physiographic province is approximately defined by the 4500-meter contour, and extends in an ESE direction between latitudes $12^{\circ} \mathrm{S}$ and $16^{\circ} \mathrm{S}$ and between longitudes $148^{\circ} \mathrm{E}$ and $155^{\circ} \mathrm{E}$. To the northwest of the Coral Sea Abyssal Plain lies the Papuan Plateau, adjacent to the continental slope of Papua. To the southwest, the Queensland Plateau is situated marginal to northeastern 


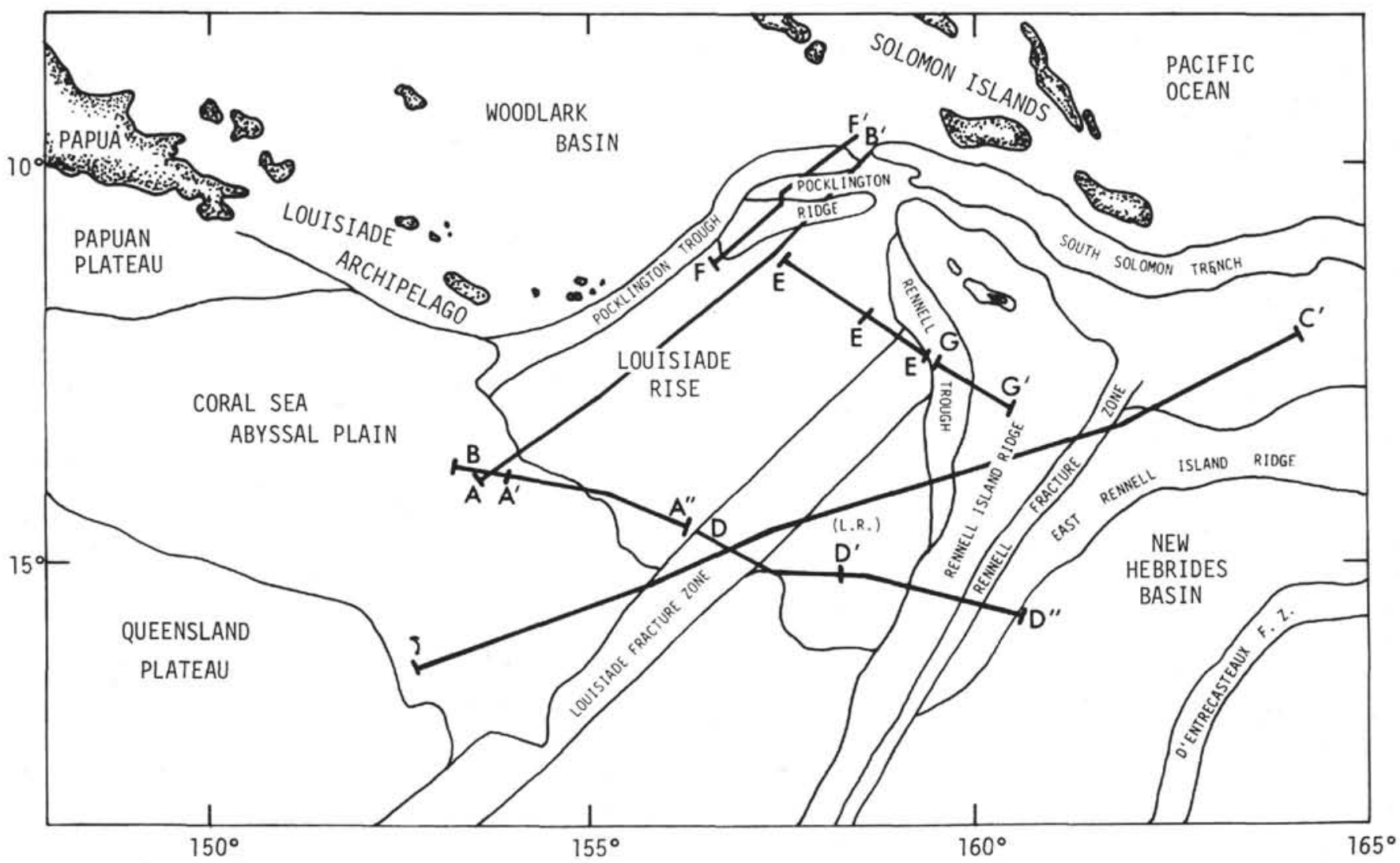

Figure 2. Physiographic provinces in the vicinity of the eastern Coral Sea Basin, southwest Pacific, and locations of seismic profiles.

Australia. The seaward extent of the Papuan Plateau is defined approximately by the 2500 -meter contour, while the Queensland Plateau, separated from the Australian continental margin by the Queensland Trough, is defined by the 1500 -meter contour. Sediment forming the Coral Sea Abyssal Plain has been transported downslope from New Guinea (Burns, Andrews, et al., 1973; Burns and Andrews, 1973) via several large submarine canyon systems which have been discussed by Winterer (1970).

The greater part of the Coral Sea Basin (east of the abyssal plain), extending northeastward to the South Solomon Trench and eastward to the Rennell Island Ridge, is characterized by complex bathymetry and a variety of morphologic features. Terrigenous sedimentation has been generally lacking, and consequently, primary features are only slightly subdued. This is in marked contrast to their almost complete burial beneath the Coral Sea Abyssal Plain. Along the northwestern margin of this area, the Pocklington Trough trends NESW along the eastern margin of the Louisiade Archipelago. This feature was first described by Krause (1967). Depths are in excess of 3500 meters, with some areas exceeding 4000 meters water depth at the southwestern and northeastern ends of the Trough.

The bathymetric high between latitudes $10^{\circ} \mathrm{S}$ and $12^{\circ} \mathrm{S}$ adjacent to the northern Pocklington Trough has been identified as the Pocklington Ridge (Krause, 1967). This ridge trends ENE-WSW. Its extent is defined approximately by the 2000 -meter contour.
Continuing along the northern boundary of the Coral Sea Basin, the sinuous South Solomon Trench occupies the area adjacent to the southern margins of Guadalcanal and San Cristobal islands. This narrow deep trends generally ESE from $158^{\circ} \mathrm{E}$ to $162^{\circ} \mathrm{E}$ longitude, at which point the trend changes to ENE until termination of the trench at approximately $165^{\circ} \mathrm{E}$ longitude. Depths in the South Solomon Trench generally exceed 4500 meters, while maximum water depths greater than 8000 meters are encountered south of San Cristobal. Numerous submarine troughs or canyons are located on both sides of the trench, with faulting and fracturing playing a dominant role in shaping the trench walls.

Separating the Coral Sea and New Hebrides basins is a prominent bathymetric high defined by the 2500 -meter contour, which trends NNW-SSE between latitudes $11^{\circ} \mathrm{S}$ and $13^{\circ} \mathrm{S}$ and continues along a southerly trend to approximately $16^{\circ} \mathrm{S}$. This ridge was first called the Rennell Island Arc by Glaessner (1950) and has been more recently referred to as the Rennell Island Ridge by Krause (1967). The coral atoll of Rennell Island is situated on this ridge. Other atolls occur along the crest of the ridge, including Bellona Island to the northwest of Rennell Island and the Indispensable Reefs to the south. A number of major and minor offsets which are related to major NE-SW trending fracture zones and associated minor transcurrent faults may be noted along the Rennell Island Ridge, as described by Taylor (1973). 
The numerous minor offsets perpendicular to the major SSW-NNE trend are characteristic of the fracture pattern developed throughout the area. Several large submarine canyons along the flanks of the Rennell Island Ridge exhibit a SSE-NNW trend, also suggestive of structural control related to the intersecting fractures.

A complex series of ridges and troughs trending SSWNNE is located to the east of the Rennell Island Ridge and a second ridge that may be its easterly extension. To the east and south of this second ridge is the more regular sea floor of the New Hebrides Basin. The ridges are defined by the 2500 -meter contour, while the 4000 meter contour outlines the narrow troughs. The eastern ridge, here called the "East Rennell Island Ridge," diverges northwards from the southern limit of the Rennell Island Ridge. Between $14^{\circ}$ and $13^{\circ} \mathrm{S}$ it trends east-west and extends eastwards to the western wall of the New Hebrides Trench north of Espiritu Santo.

The New Hebrides Basin sea floor between this ridge and the d'Entrecasteaux Fracture Zone is smoother than that to the east of the fracture zone and that to the north of the ridge. Site 286 was located in the rougher sea floor east of the fracture zone and south of the East Rennell Island Ridge.

The western part of the New Hebrides Basin is separated from the northern end of the New Caledonia Basin by a broad ridge extending from the northern end of the Lord Howe Rise to the northern end of the ridge on which New Caledonia lies.

Parallel to the western margin of the Rennell Island Ridge, a major trough is outlined by the 3000 -meter contour. The name "Rennell Trough" is used herein for this feature, which has maximum depths greater than 4000 meters.

The area between the Pocklington Trough to the west and the Rennell Trough to the east is characterized by two WNW-ESE trending rises collectively called the Louisiade Rise. The northwestern part is outlined by the 2000-meter contour. The northeastern flank of the Louisiade Rise is bounded by the Rennell Trough. A large, elongate deep, trending WSW-ENE, terminates the northwestern segment of the Louisiade Rise on the southeast. This deep is defined by the 4000 -meter contour. Continuing to the southeast, the other bathymetric smaller high is encountered, with depths ranging between 2000 and 3000 meters. This rise, regarded as the southeastern continuation of the Louisiade Rise to the northwest, is terminated on the east by the southern part of the Rennell Trough. Its southwestern margin is indistinct, merging into a series of broad ridges and troughs.

\section{ANALYSIS OF SEISMIC REFLECTION PROFILES}

Based on continuous seismic reflection profiles, the structure and sediment distribution across a number of the physiographic features in the eastern Coral Sea Basin have been defined. The results of this analysis are presented in Chart 2 (in back pocket of volume) and discussed below. In certain areas where profiles are not available, structural trends have been inferred from detailed bathymetry (Chart 1). In the following discus- sion, total reflection time to a reflector is used rather than subbottom reflection time. The location of seismic reflection profiles presented herein is shown in Figure 2.

\section{Coral Sea Abyssal Plain}

In the Coral Sea Abyssal Plain, a thick sequence of acoustically stratified turbidites overlies a prominent reflector at approximately $6.8 \mathrm{sec}$. This reflector, identified by Andrews (1973) as the top of mid-Oligocene to late Oligocene nannofossil chalk cored at DSDP Site 210 (Figure 3), shows moderate relief suggestive of rough basement topography. A deeper reflector appears in some areas, and may be traced to the basement ridge in the center of Profile AA' (Figure 4). Based on a comparison of sedimentation at DSDP Sites 210 and 287, this basement high was formed prior to early Oligocene, possibly during initial development of oceanic crust in the early Eocene (see Chapter 5, this volume). Similar basement structures appear on other reflection profiles across the area (Ewing et al., 1970), and the site survey at DSDP Site 287 suggests an en echelon pattern of development.

On the western end of the profile at the foot of the Queensland Plateau, a transparent sequence is overlain by a succession containing a number of reflectors. In this region a basement reflector is clearly visible. It rises to the east. This situation along the edge of the plateau has been interpreted by Falvey and Taylor (1974) largely on the basis of seismic refraction and gravity data. They have interpreted the basement at the foot of the slope as the outer edge of the continental crust. The overlying acoustically transparent section would represent Late Cretaceous to Paleocene sediments deposited in rifts formed immediately prior to the development of the Coral Sea. The upper sequence containing the frequent reflectors would then be the Eocene and younger sequence deposited after breakup and subsidence of the continental margin.

The eastern boundary of the Coral Sea Abyssal Plain is marked by a basement ridge, which extends south of the Louisiade Rise (Figure 4). In Profile AA' (Figure 4), the thick abyssal plain turbidites appear to overlie a series of slump deposits at the base of the ridge. This unconformity suggests that slumping from the ridge predates deposition of the turbidites (mid Miocene). Moreover, ponded sediments covering the faulted basement near the top of the ridge postdate basement faulting. The date of faulting of this structure is difficult to determine, it might have been after the accumulation of a significant thickness of biogenic sediments or slumping might have taken place from time to time as sediment accumulated on the faulted surface. The faulting is probably related to a broad fracture zone trending NESW toward the Rennell Island Ridge.

Near the northeastern margin of the Coral Sea Abyssal Plain, a NW-SE trending ridge is defined by bathymetric contours on Chart 1. Ewing et al. (1970) have presented a profile across this structure, showing it to be a basement feature, characterized by normal faulting toward the southwest and possible tilting of the basement surface and overlying sediments toward the 


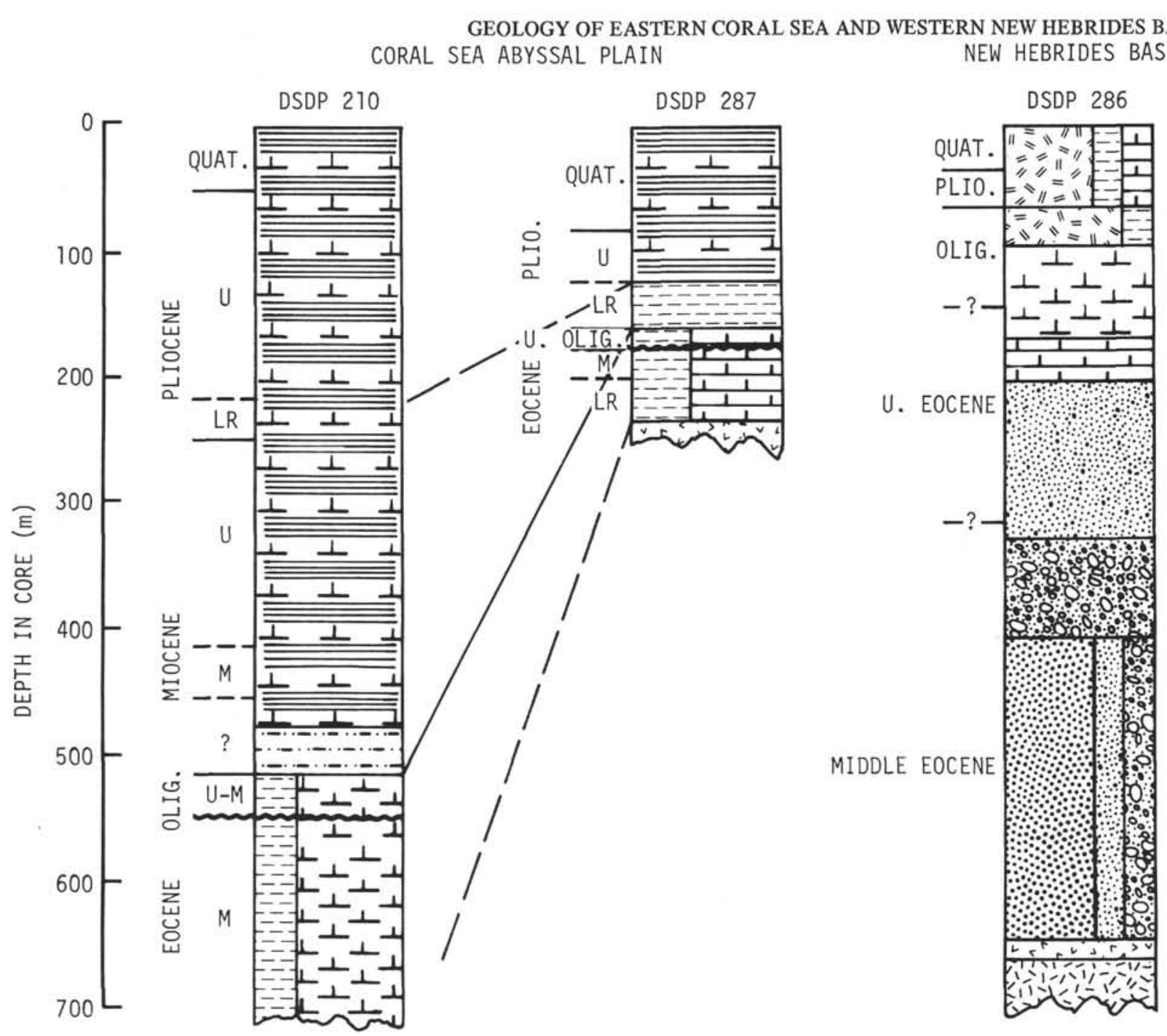

STRATIGRAPHY
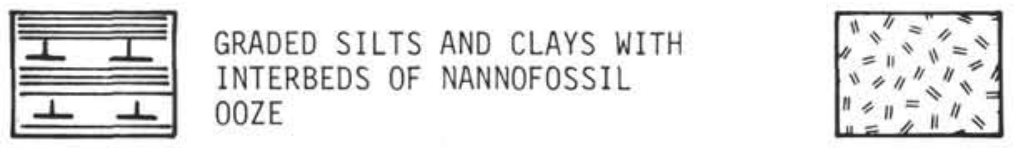

GLASS SHARD ASH
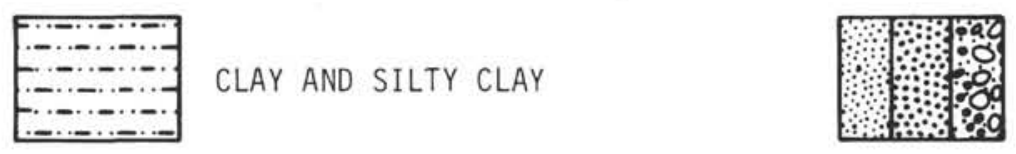

VOLCANOGENIC SILTS, SANDS, AND CONGLOMERATES
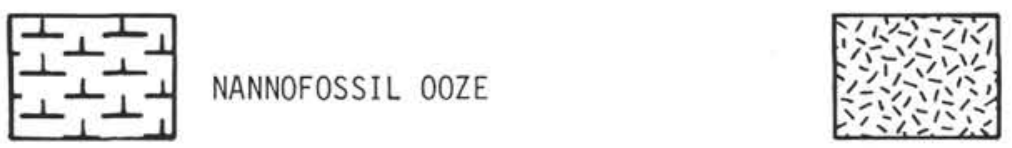

GABBRO

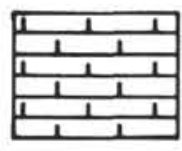

NANNOFOSSIL CHALK

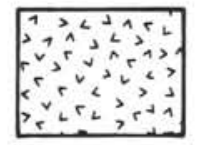

BASALT

REGIONAL UNCONFORMITY

Figure 3. Stratigraphic columns: DSDP Sites 210 and 287 (Coral Sea Abyssal Plain); DSDP Site 286 (New Hebrides Basin). 


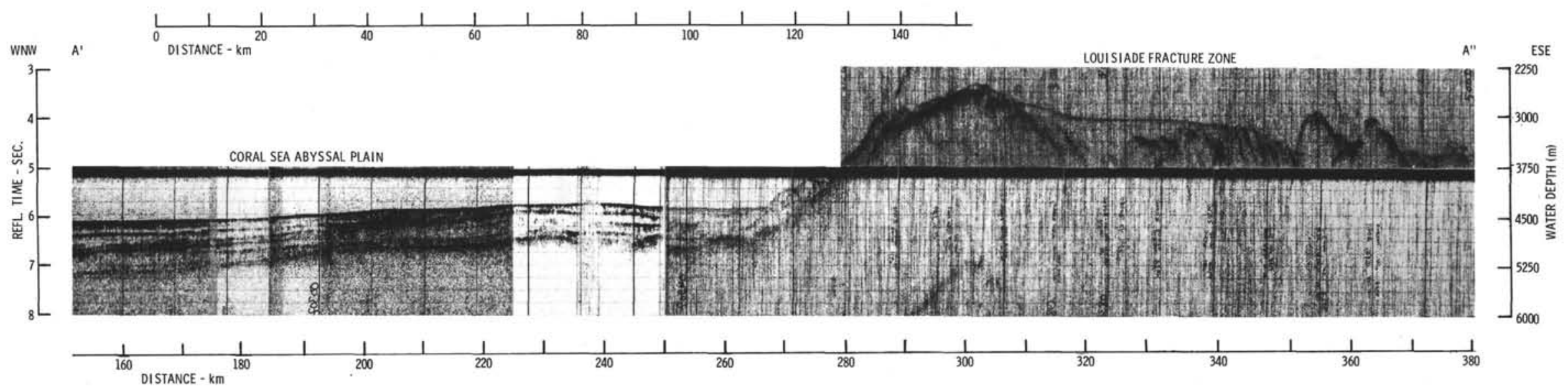

Figure 4. Reflection Profile AA'A": Coral Sea Abyssal Plain to Louisiade Fracture Zone. 
northeast. Its development may be related to downfaulting on the southwestern flank of the Louisiade Rise.

Tectonic activity postdating the initiation of turbidite deposition is indicated in Profiles $\mathrm{AA}^{\prime}, \mathrm{BB}^{\prime}$, and $\mathrm{CC}^{\prime}$, (Figures 4, 5, and 6) in which the surface of the turbidites and some of the deeper layers show disturbance. This is particularly apparent in Profile BB' in which turbidites extend some distance up the slope of the Louisiade Rise indicating elevation of the rise.

\section{Louisiade Rise}

The Louisiade Rise (Figure 5) appears to be both a major physiographic and structural feature in the eastern Coral Sea Basin. The flanks of the rise are characterized by normal faulting away from the rise crest, and piercement structures are present in several areas. These structures suggest that tensional stress has played the dominant role in forming the Louisiade Rise.

A thick, moderately stratified sedimentary sequence overlies basement, and based on interpolation from DSDP Sites 210 and 287, is probably dominated by calcareous ooze resulting from pelagic deposition since Eocene time. The prominent reflector at $0.3 \mathrm{sec}$ below the sediment surface may be within the Eocene. Small troughs on the rise contain up to $0.7 \mathrm{sec}$ of sediment (two-way travel time). The character of the profiles across the rise resemble those across the Queensland Plateau. The small troughs of sediment there have been interpreted by Falvey and Taylor (1974) as Late Cretaceous to Paleocene clastic sediments.

The late Eocene-early Oligocene regional unconformity reported by Burns and Andrews (1973) would also be expected in the stratigraphic section of the Louisiade Rise. Erosional features characterize the present surface of the rise and are particularly evident near its crest where numerous scour channels may be seen. Subsurface reflectors appear to be truncated along the southwestern margin, creating an unconformity which has probably resulted from bottom current scour or from turbidity currents moving downslope from the crest of the rise toward the Coral Sea Abyssal Plain. Interbeds of nannofossil ooze with Oligocene forms reported in the turbidite sequence at DSDP Site 210 (Burns, Andrews, et al., 1973) and Site 287 (see Chapter 5 , this volume) may possibly be traced to a source area on the Louisiade Rise.

The extension of the rise to the southeast (Charts 1 and 2) appears to be similar in character to the northwestern Louisiade Rise (Profile CC', Figure 6 and Profile DD', Figure 7, center). The sedimentary section is comprised of moderately stratified deposits, probably dominated by pelagic biogenic components. Reflectors within the sedimentary column dip away from the rise crest and appear truncated at the rise crest where erosional features are dominant. Erosion has left only a thin veneer of sediment covering basement near the rise crest, making the area a favorable site for future sampling.

A fault bounded trough trending NE-SW appears to separate the Louisiade Rise proper to the northwest from this rise segment to the southwest (Charts 1 and 2).
Profile DD' (Figure 7) shows a section across this trough (left) and the flank of the rise (center). A complete section across this area is presented in Profile CC' $^{\prime}$ (Figure 6) (center). The eastern side of the trough is characterized by several basement ridges with "deformed" sediment between.

The NE-SW trending trough may in part represent a fracture zone that is herein named the Louisiade Fracture Zone. The basement ridges along the trough margins appear to trend NNE-SSW, their abundance and distribution suggests that they may be a series of "feather fractures," oblique to the main fracture and similar to the type discussed by Andrews (1971) in the northeastern Pacific. In this case the main fracture, probably a transform fault, probably trends as indicated on Chart 2, or alternatively the small faults may themselves represent a series of small transform faults. Geometrically this latter seems more likely (see below).

Normal faults are also abundant, surrounding both rises (Chart 2), and probably represent secondary structures developed prior to significant sediment accumulation. Profile $\mathrm{EE}^{\prime} \mathrm{E}^{\prime \prime}$ in Figure 8 shows a section across the northeastern margin of the Louisiade Rise and the northern extension of the Louisiade Fracture Zone. A number of well-defined grabens dominate the area, and undeformed sediments suggest that these basement structures developed early in the geological history of the region.

Whether the crust constituting these rises is oceanic or continental cannot be determined with certainty on the basis of the available data. If Falvey and Taylor (1974) are correct in suggesting that continental crust extends down to the foot of the Queensland Plateau into water depths of around 4000 meters, then it is possible that the whole of this rise region could be continental. It might further be pointed out that the rises have water depths comparable with that of the Papuan Plateau. Only the trough between the two rise segments is of a depth comparable to that of the Coral Sea Abyssal Plain. As already stated, the sediments on the Louisiade Rise have similar structure and seismic character to those on the Queensland Plateau. On a continental crust interpretation the Louisiade Rise represents an extension of the Queensland Plateau crust rifted off during the formation of the Coral Sea, and the fracture zone is the result of a transform fault passing between two blocks of continental crust possibly related in some way to complexities in the development of the Coral Sea crust.

The equally uncertain alternative view is that the rises are underlain by oceanic crust. It was suggested that the rise is covered by Eocene sediments and should have an age (if oceanic) generally comparable to that of the Coral Sea. The depth of the rise is, however, very much shallower than would be expected for its age. Sparse magnetic data are available from the region and those observed on the crossing of this feature on Leg 30 of DSDP are shown in Figure 5. The anomalies show some semblance of symmetry about the ridge crest. If one starts with the established age of the sea floor at Site 287 (about anomaly 21) then the age at the ridge crest counting the anomalies is 17 (42 m.y.). There is a rough match between these anomalies and the observed shapes 
B

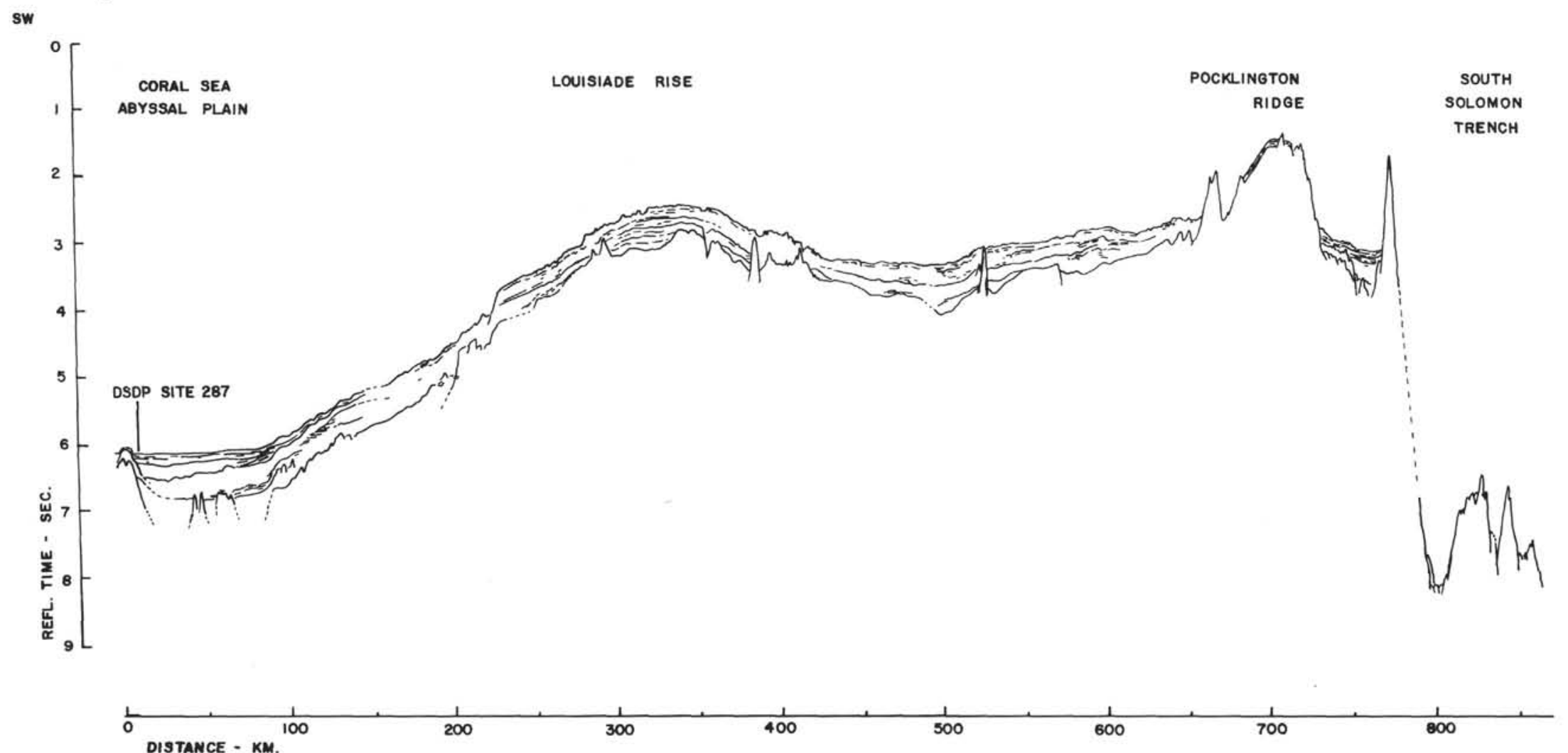

Figure 5. Reflection Profile BB': Coral Sea Abyssal Plain to South Solomon Trench. 


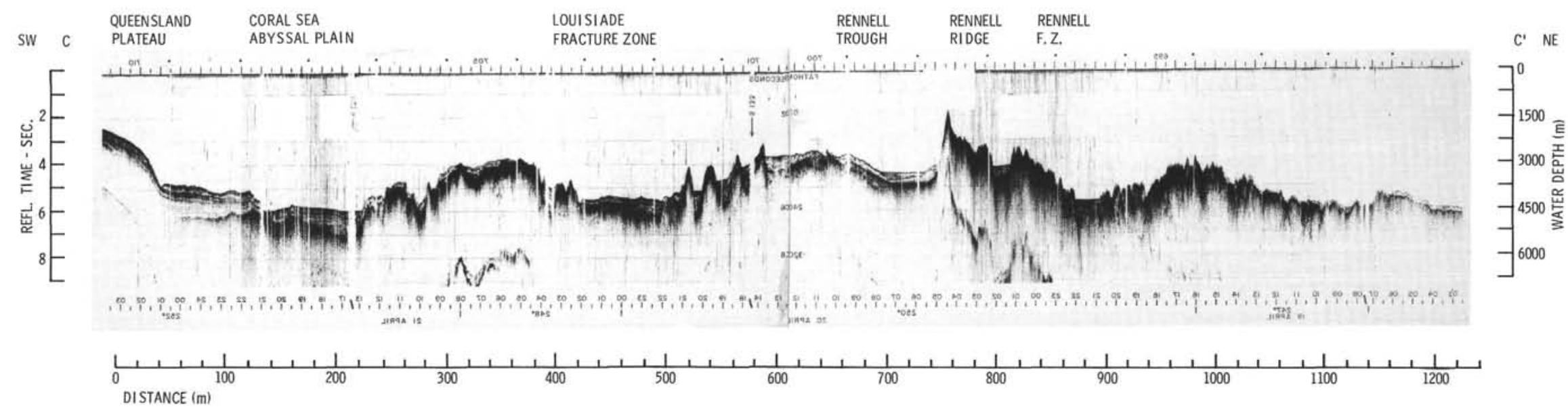

Figure 6. Reflection Profile CC': Queensland Plateau to Rennell Fracture Zone.

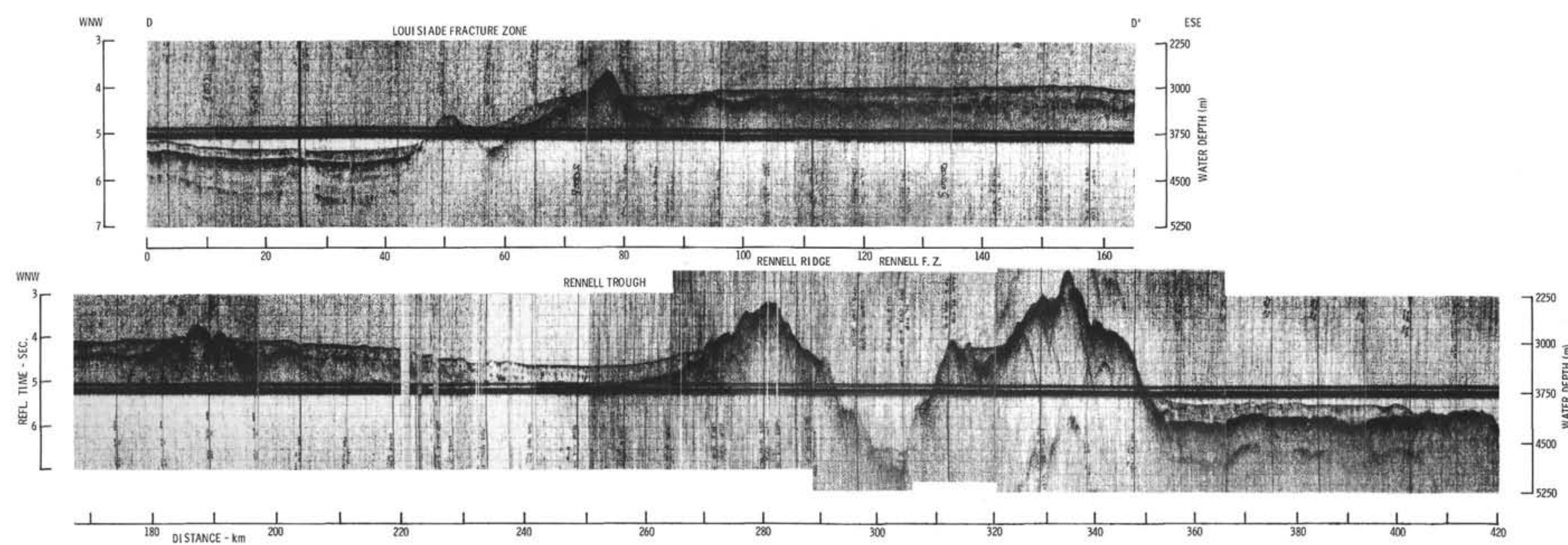

Figure 7. Reflection Profile $D D^{\prime} D^{\prime \prime}$ : Louisiade Fracture Zone to Rennell Fracture Zone. 
NW E

E' SE

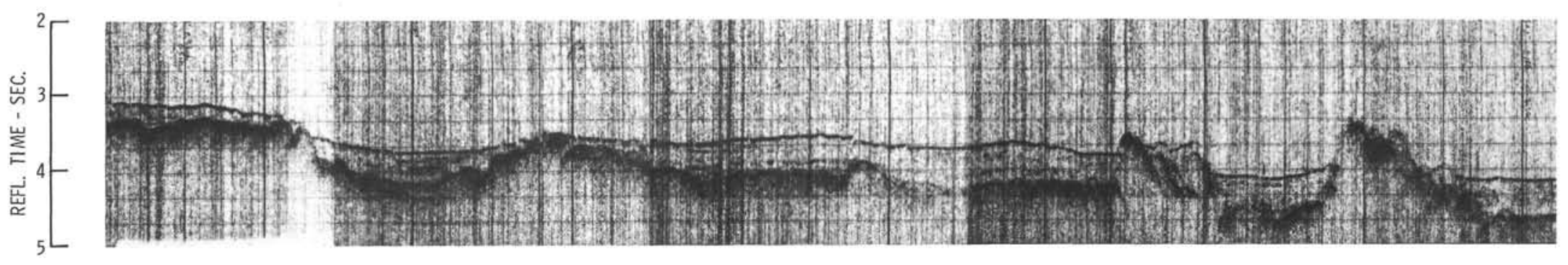

$-_{3750}^{2250}$

$$
\text { L }
$$

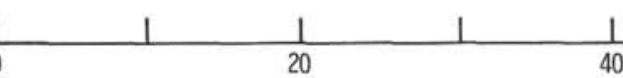

DISTANCE - km

$\frac{1}{40}$
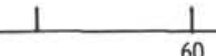

60
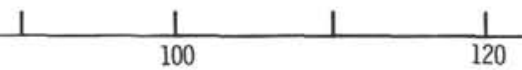

120

E"

$E^{\prime}$

LOUISIADE FRACTURE ZONE
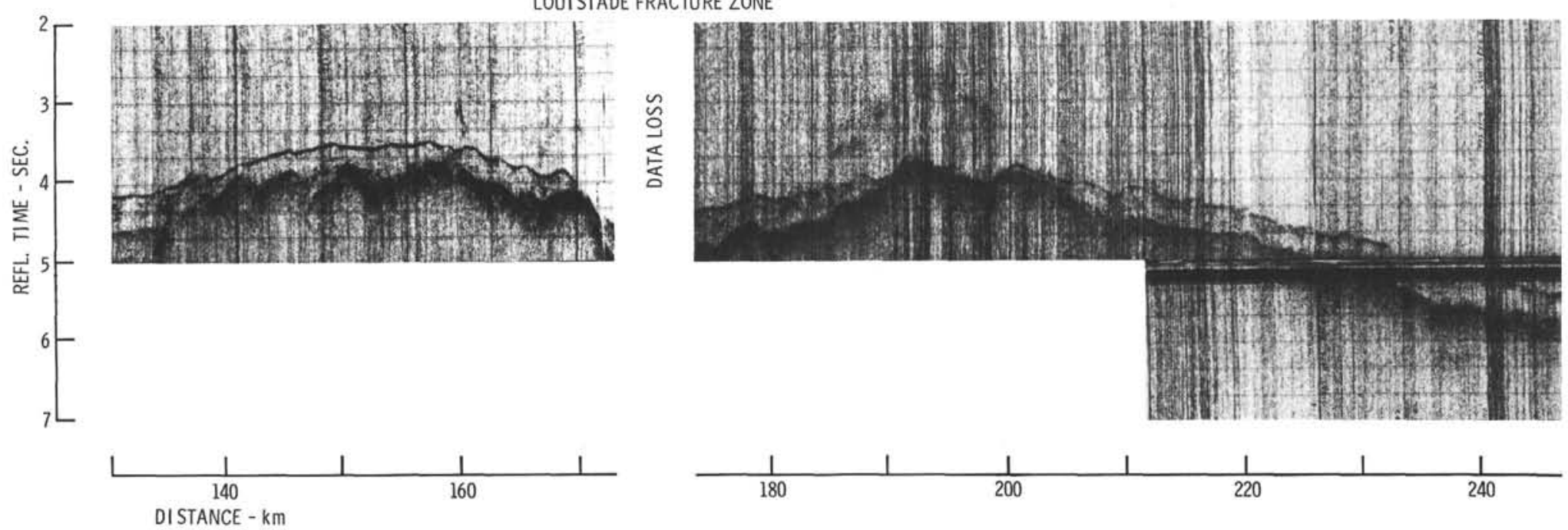

$--^{2250} 3000 \frac{\bar{E}}{1500}$

Figure 8. Reflection Profile EE' $E^{\prime \prime}$ : Northern flank of Louisiade Rise to Louisiade Fracture Zone. 
and spacings. While there is a great deal of uncertainty attached to this interpretation, it provides a speculative explanation of the origin of the sea floor. The half spreading rate would be less than $2 \mathrm{~cm} / \mathrm{yr}$. Continuation of spreading at this rate would give the basin a maximum age of 63 m.y. (early Paleocene). The shallow depth of the rise may be explained by the formation of thicker crust associated with the cessation of spreading. However, the argument must be regarded as highly tenuous since when an attempt was made to correlate these anomalies observed on Leg 30 with the ones available in the area from the Nova Expedition, it was unsuccessful. On the oceanic crust spreading ridge interpretation, the two rise segments would form part of an old spreading ridge separated by a transform fault. The Pocklington Trough would probably represent another transform feature being essentially parallel to the Louisiade Fracture Zone. The Louisiade Ridge has no equivalent west of the Pocklington Trough, nor is there a symmetrically disposed segment of sea floor north of the Louisiade Rise corresponding to the abyssal plain sea floor between the Louisiade Rise and the Queensland Plateau. A fanciful explanation for these relationships is that spreading ceased in the western Coral Sea, and the spreading ridge moved to the Solomon Sea north of the Papuan Peninsula while spreading continued in the western Coral Sea. The crust equivalent to that under the Coral Sea Abyssal Plain may have been lost by subduction under the Rennell Island Ridge or in the South Solomon Trench. The possibility of asymmetrical spreading cannot be ruled out. The Pocklington Trough is probably more complicated than a simple transform feature since it has associated with it a negative free air gravity anomaly in excess of 100 milligals (Falvey and Taylor, 1974).

\section{Pocklington Ridge}

Sections across the ENE-WSW trending Pocklington Ridge are shown in Profile BB' (Figure 5) northeast of the Louisiade Rise, and in greater detail in Profile FF $^{\prime}$ (Figure 9). This feature is characterized by a faulted basement surface, overlain by sediment of variable thickness. Basement outcrops appear in a number of areas. Normal faulting is dominant on the flanks of the ridge, with fault planes dipping away from the ridge crest (Chart 2). The sedimentary sequence is generally much thinner than on the Louisiade Rise, suggesting that the Pocklington Ridge is a more recent structural feature or has been subject to more current scouring.

A further problem exists deriving from the form of the western Coral Sea. Its shape suggests that for simple opening the pole of rotation would have lain in central or western Papua-New Guinea. Transform faults in the vicinity of the Louisiade Rise should trend at about $30^{\circ}$ and the spreading ridge at about $120^{\circ}$. These directions are at variance with those shown on Chart 2 . The small faults parallel to the trough between the two sections of the Louisiade Rise are close to that of the predicted transform and the Rennell Fracture Zone (see discussion below). The axis of the suggested spreading ridge shown on the chart is based on the topographic ridge trend.
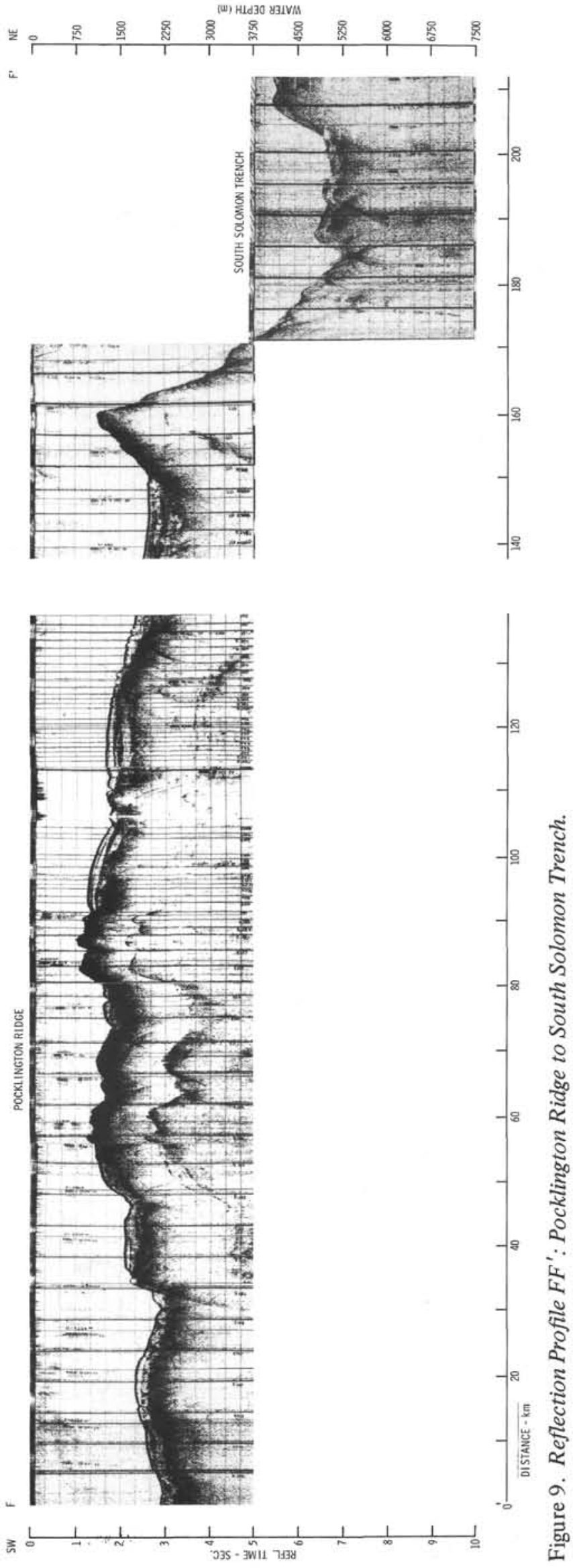
RENNELL TROUGH

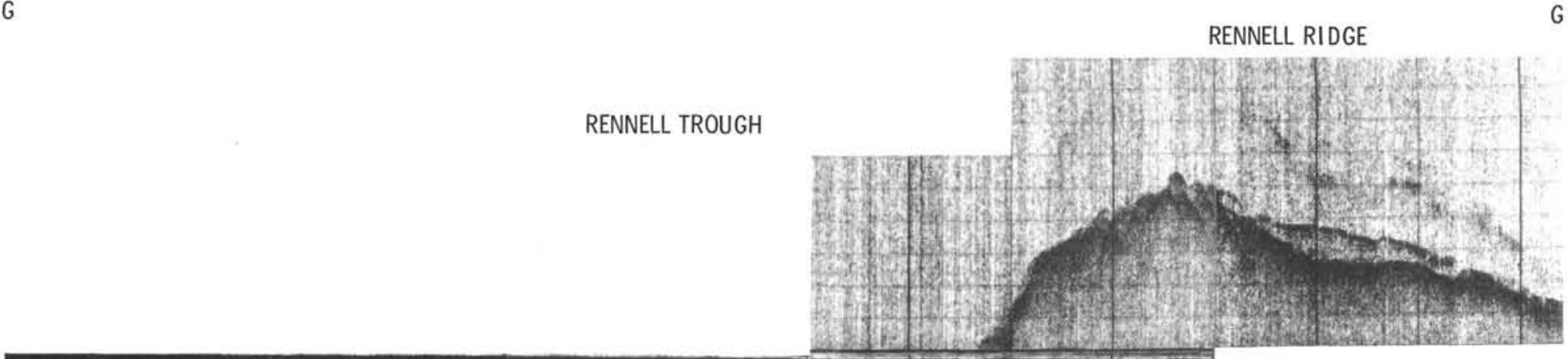

G SE

$7^{1500}$

2.7.

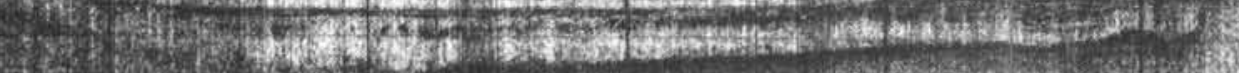

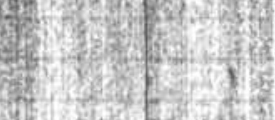

1.

H.

$-2250$

$2250+\frac{1}{5}$

$-3000$

-3750 豆

1

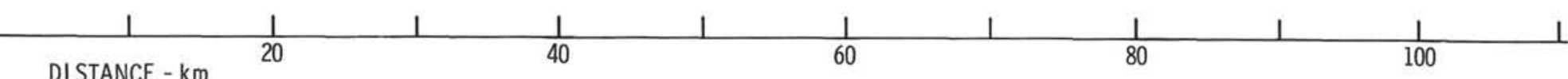

Figure 10. Reflection Profile GG': Rennell Trough to Rennell Island Ridge. 
The Pocklington Ridge may be a constructive feature formed as a result of submarine volcanism, alternatively it may be a submerged extension of the Mesozoic metamorphics outcropping in the Louisiade Archipelago west of the Pocklington Trough. The Leg 30 DSDP magnetic profile showed low amptitude short wavelength anomalies over the ridge. This would tend to support the latter view.

The northern surface of the Pocklington Ridge is characterized by a number of shallow normal faults (Figure 9, Profile FF' right of center). These faults are probably related to tension in the upper lithosphere produced by crustal warping in response to subduction along the South Solomon Trench.

\section{Rennell Island Ridge-East Rennell Island Ridge-Rennell Trough}

The Rennell Island Ridge, forming the eastern boundary of the Coral Sea Basin, appears on reflection profiles to vary in structure and morphology progressing from north to south. Sections across the northern part of the ridge, between $11^{\circ} \mathrm{S}$ and $12^{\circ} 20^{\prime} \mathrm{S}$, are shown in Figures 6, Profile CC', and 10, Profile GG' (right of center). Sediment is generally lacking on the relatively steep flank of the ridge, while coral growth has occurred along its crest, as indicated by the presence of the coral atolls of Bellona Island, Rennell Island, and Indispensable Reefs. Taylor (1973) has suggested that more than 500 meters of carbonate sediments and reef limestones have been deposited over basement during general subsidence of the ridge since its initial formation. However, in Figures 6 (Profile CC') and 10 (Profile GG'), coral growth appears limited on the ridge crest, indicating that certain areas have been well below sea level since its development or it subsided rapidly. The relatively steep western slope of the Rennell Island Ridge is characterized by normal faulting toward the west.

The Rennell Trough, adjacent to the western margin of the ridge, is floored by flat-lying stratified sediments, over-lying an acoustically transparent sedimentary section that more closely follows the basement configuration. This relationship is especially well defined in Figure 6 (Profile $\mathrm{CC}^{\prime}$ right of center) which crosses perpendicular to the NNW-SSE structural trend. A wedge of the deeper sediments outcrops at the base of the Rennell Ridge, creating an angular unconformity with the overlying horizontal sediments so that the relationship resembles that on the eastern side of the Coral Sea Abyssal Plain on Profile AA" (Figure 4). The structure of the lower (transparent) sediments may be due to northeast compression that has taken place since their deposition or could have resulted from slumping of the older sequence.

South of $15^{\circ} \mathrm{S}$ the Rennell Trough is shallower than it is to the north, but a similar relationship may be seen in the sedimentary section. Figure 7 (Profile $\mathrm{DD}^{\prime} \mathrm{D}^{\prime \prime}$ ) presents a section across the southeastern Coral Sea Basin, crossing a part of the southern Rennell TroughRennell Island Ridge. A thin layer of stratified sediments lies unconformably on acoustically transparent deposits.
The southern Rennell Island Ridge appears to have a slightly different structure than that discussed above for the northern ridge, probably due to tectonic overprinting. A section across the southern part of the ridge is shown in Figure 7 (Profile $\left.D^{\prime} D^{\prime \prime}\right)$. Here, the ridge is bisected into the Rennell Ridge and the East Rennell Island Ridge by a large graben feature. Normal faulting toward the axis of the trough is dominant. A piercement structure may be seen intruding ponded sediments on the right (ESE) flank of the trough, suggesting magmatic activity along parts of the ridge. When located on the bathymetric chart of the area (Chart 1), this trough appears to be one of a complex series of troughs and associated ridges (collectively the Rennell Fracture Zone) trending NE-SW, toward the South Solomon Trench. The northern part of this complex, north of $15^{\circ} \mathrm{S}$, is broader than to the south, with several parallel troughs commonly offset along NW-SE linaments, perpendicular to their NE-SW trend (Chart 1). A section across this region is presented in Figure 6 (Profile CC' $^{\prime}$ ), east of the Rennell Island Ridge. It crosses the northern flank of the East Rennell Island Ridge. Sediments within the troughs appear to have been deformed showing relationships similar to those in the Rennell Trough.

It is apparent from the bathymetric map and the profiles across the Rennell Trough that only the northern part south of Rennell Island reaches oceanic depths $(<4000 \mathrm{~m})$ the remainder is less than 3500 meters deep. The elevation of the shallower part of the trough relative to New Hebrides Basin is shown in Profiles $\mathrm{CC}^{\prime}$ and $\mathrm{D}^{\prime} \mathrm{D}^{\prime \prime}$ (Figures 6 and 7). This being so, only the crust of the northern part can be taken as almost certainly oceanic. The southern part is subject to the same ambiguity as the Louisiade Rise-it could be underlain by oceanic or continental crust.

The Rennell and East Rennell Island ridges are sufficiently shallow to make them unlikely to be oceanic or substantially so. Two main alternatives that may apply to all or part of the ridge complex can be proposed. The simplest possibility is that the ridges represent disrupted fragments of the Gondwanaland continental margin probably composed of Mesozoic sialic metamorphics, linking the New Caledonia metamorphics to those in the Louisiade Islands and the Papuan Peninsula. The second is that the ridge may represent a segment of the Eocene volcanic arc that supplied the volcanogenic turbidites to Site 286 in the New Hebrides Basin; the subduction zone would have presumably been on the northern side.

The Rennell Fracture Zone that separates the Rennell Island Ridge and the East Rennell Island Ridge is a feature that trends at $30^{\circ}$ in the area of Chart 1 . The deep troughs and evidence of magmatic activity along it suggest that it contains areas of oceanic crust. The most likely interpretation of the structure is a transform fault. The trend of this structure to the south is crucial in attempting to determine its age and tectonic significance. It is possible that the structure continues on much the same trend and links up with the fractures intersected on the Leg 21 profile north of the Dampier Ridge (see figure 3, Burns and Andrews, 1973), or 
that it swings towards a more easterly trend and links with fractures seen on the same profile on the southern margin of the Queensland Plateau.

In the former case the trend is compatible with the transform direction between the Pacific and India plates for the interval 29 to 38 m.y. (latest Eocene to early Oligocene), as determined by Packham and Terrill (this volume). If this transform was part of the plate boundary during that interval, then the subduction of part of the Tasman Sea under eastern Australia as suggested by Hayes and Ringis (1973) could be a consequence of such a location for the Pacific-India plate boundary.

This scheme would be in agreement with their observation that the amount of subduction decreases southwards since the pole is located at about $163^{\circ} \mathrm{W}$, $43^{\circ} \mathrm{S}$. South of Australia the motion would probably be a transform fault.

The plate boundary immediately prior to this was probably located in New Caledonia and the d'Entrecasteaux Fracture Zone where obduction and transform motion are suggested (see below).

The second alternative interpretation of the Rennell Fracture Zone is that it was a transform fault formed between two ridge segments during the opening of the Coral Sea, linking a spreading axis in the New Hebrides Basin with one in the Coral Sea Basin. In this case the minor faults crossing the Louisiade Rise would also be transform faults and the spreading axis, if located on the Louisiade Rise, should be perpendicular to them. The wedge-shaped form of the western Coral Sea indicates, as stated previously, that the pole of opening was located not far away, probably in central or western Papua-New Guinea. The trend of the transform faults would then be expected to trend in a more easterly direction when followed to the south.

The significance of the northern part of Rennell Trough is even more difficult to establish than that of the other features discussed. A wide number of possibilities are open. Two are: (a) it may constitute a small patch of sea floor developed during the development of the Coral Sea north of the Louisiade Rise continental crust, or (b) it may be a small patch of deeper oceanic crust corresponding to the Coral Sea Abyssal Plain developed during the earlier more rapid spreading from the Louisiade spreading center.

The tentative suggestion is made on Chart 2, on the basis of the possible deformed sediment in the trough, that this may be a zone of underthrusting. However, the configuration of the basement in the profiles does not confirm this hypothesis. The fault indicated on the map is the maximum extent it could have had. Some convergence in the northern section of the trough between it and the Rennell Island Ridge is geometrically possible in the Oligocene if the Rennell Trough was part of the Pacific-India plate boundary. It could have been part of the convergent plate boundary that may have been present in New Guinea at this time.

\section{New Hebridges Basin and} d'Entrecasteaux Fracture Zone

In the New Hebrides Basin to the east of the d'Entrecasteaux Fracture Zone an Eocene basement age has been established at DSDP Site 286 (Figure 3) near the New Hebrides Trench.
The sea floor east of the fracture zone has a cover of Eocene volcaniclastic turbidites that have been deformed. These are overlain by late Eocene to Oligocene biogenic ooze, then by Miocene abyssal clay. Overlying these are clastic Pliocene to Plesitocene sediments. The Pliocene and Pleistocene sediments are flat lying and fill hollows. It is not known whether the oozes and abyssal clays are unconformable on the turbidites. Packham and Terrill (this volume) suggest that the deformation took place in the early Oligocene when there was an active plate boundary in the region as indicated by the obduction of ultramafic bodies onto New Caledonia. The d'Entrecasteaux Fracture Zone discussed below could have been part of this same plate boundary. The latest date possible for the deformation is Miocene, after the deposition of the abyssal clay.

The d'Entrecasteaux Fracture Zone is expressed on the Leg 30 DSDP crossing as an east-facing scarp 2000 meters high (see Chart 1). The deepest sediments in the narrow trough on the east of the scarp dip to the west, suggesting underthrusting from the east. Later sediments in the trough are flat lying. To the west of the scarp, the sea floor and its sedimentary cover slope gently to the west. Flat-lying sediments (presumed to be turbidites) occupy some of the depressions. The bathymetry suggests that the flat-lying sediments here and those in the trough immediately east of the fracture zone were probably derived from the New Caledonia and Loyalty ridges. The Pliocene and Pleistocene sediments at Site 287 were derived from the New Hebrides. The quality of the seismic records available is not sufficiently good to say whether the sediments resting on the basement west of the d'Entrecasteaux Fracture Zone are an extension of the volcaniclastic turbidites drilled at Site 286. The character of the basement on each side of the fracture zone is, however, quite different; on the east the wavelength of basement features is 10 to $20 \mathrm{~km}$ while on the west it is over $50 \mathrm{~km}$. This difference may be attributed the location of the plate boundary at the fracture zone at the time of the obduction of sea floor onto New Caledonia so that only the east was deformed on a small scale.

\section{SUMMARY OF THE TECTONIC HISTORY}

Formation of the Coral Sea Abyssal Plain and the New Hebrides Basin sea floor took place in the Eocene. In the Coral Sea region rifting of the Australian continental margin took place. Spreading may have centered on the Abyssal Plain extending south into the Cato Trough-Mellish Reef area off the Queensland coast. Additional small areas of oceanic crust have developed (the Rennell Trough and the area of sea floor between the two sections of the Louisiade Rise). The Louisiade Rise could be an area of submerged continental crust. The Rennell Island Ridge and the East Rennell Island Ridge could also be continental or be partly or completely built up of island arc volcanics with a trench formerly developed to the north. This is suggested because of the thick volcanogenic turbidite sequence in the New Hebrides Basin. If any part of these ridges was an island arc, it is more likely to be the East Rennell Island Ridge. The Rennell Fracture Zone could be a major fracture zone separating the Coral Sea and the 
New Hebrides Basin spreading centers. The geometry of motion is apparently generally consistent with the pole of opening of the Tasman Sea.

An alternative interpretation of the Louisiade Rise is that it is a spreading ridge cut into two main segments by transform faults.

The Eocene sediments of the Coral Sea are biogenic with a minor terriginous content. These biogenic sediments occur on the rises and beneath the abyssal plain. Island arc volcanics provided Eocene volcaniclastic turbidites to the New Hebrides Basin in the middle Eocene with the volcanism dying out in the late Eocene.

\section{Oligocene}

The Pacific-India plate boundary was located in New Caledonia in the early Oligocene and the convergent plate motion obducted oceanic crust and upper mantle material onto New Caledonia. The d'Entrecasteaux Fracture Zone could have been essentially a transform fault section of this plate boundary with minor underthrusting. Possibly contemporaneous with the obduction was deformation of the sea floor of the New Hebrides Basin and the elevation of the Loyalty Ridge. The deformation stops abruptly at the d'Entrecasteaux Fracture Zone. To the west the convergent plate boundary may have gone along the south side of the east-west part of the Rennell Island and East Rennell Island Ridges as a short-lived subduction zone linking eventually with the obduction zone of the Papuan Ultramafic Belt perhaps via the Pocklington Trough. The overthrusting may have occurred at this time (D. Dow, personal communication) rather than in the Eocene as suggested by Davies and Smith (1971).

As an alternative to the origin suggested above, the Rennell Fracture Zone may have been formed in the Oligocene by relocation of the India-Pacific plate boundary after the obduction occurred in New Caledonia. The fracture zone would have extended to the eastern Australian coast and then the plate boundary extended along the eastern Australian coast southwards. The expected convergent plate motion that took place with this could explain the subduction of part of the Tasman sea floor under eastern Australia suggested by Hayes and Ringis (1973).

The sediments deposited at this time were predominantly biogenic. A hiatus in deposition attributable to the distribution of oceanic currents (Kennett et al., 1972) occurs in the Coral Sea-Lord Howe Rise-Queensland Plateau region but not in the New Hebrides Basin presumably due to a physiographic barrier to deep currents. Some clastic sediments may have been deposited near the Rennell Ridges and near New Caledonia if they were elevated above sea level.

\section{Miocene and Later}

Subsidence of the sea floor of the Coral Sea Abyssal Plain and much of the New Hebrides Basin below the depth of total dissolution of nannofossils resulted in the deposition of abyssal clays. In the Coral Sea Abyssal Plain deposits the abyssal clay is followed in the middle Miocene by the onset of turbidite deposition which is still continuing. The clastics were derived from the uplifted regions of the Papuan Peninsula and perhaps as far afield as northern New Guinea. Some uplift of the abyssal plain sediments is evident on the southern flank of the Louisiade Rise and the eastern part of the abyssal plain.

Clastic sediments have also been derived from New Caledonia, the Loyalty Islands, and Rennell Island and deposited in the New Hebrides Basin and Rennell Trough. These sediments probably contain a significant bioclastic component coming from the reef complexes developed around these islands and on the adjacent ridges.

Early Pliocene to Pleistocene sediments also came into the New Hebrides Basin from the east with an increasing rate of sedimentation as the New Hebrides Islands moved westwards due to the convergence of the Pacific and India plates and the development of the Fiji Plateau. Shallow water detritus in the early Pleistocene sediments indicates the partial blocking of the New Hebrides Trench from at least that time onwards.

\section{ACKNOWLEDGMENTS}

The authors are grateful to the many individuals who devoted their time and effort acquiring and reducing shipboard data and preparation of charts. We would like to acknowledge the benefit we have gained from discussions with colleagues, notably Drs. L.W. Kroenke and D.A. Falvey. Special thanks are extended to Dr. John I. Ewing of LamontDoherty Geological Observatory for seismic reflection profiles obtained during cruises of the R/V Vema in 1966, and to The Hydrographer, Royal Australian Navy, for contributing much of the bathymetric data used in constructing charts of the eastern Coral Sea Basin. Thanks are also extended to $\mathrm{Mr}$. Richard Rhodes and the staff of the Hawaii Institute of Geophysics graphic department for drafting charts and illustrations. This study was made possible by support from the Office of Naval Research and the National Science Foundation.

\section{REFERENCES}

Andrews, J.E., 1971. Abyssal hills as evidence of transcurrent faulting on North Pacific fracture zones: Geol. Soc. Am. Bull., v. 82 , p. $463-470$.

1973. Correlation of seismic reflectors, In Burns, R.E., Andrews, J.E., et al Initial Reports of the Deep Sea Drilling Project, Volume 21: Washington (U.S. Government Printing Office), p. 459-479.

Burns, R.E. and Andrews, J.E., 1973. Regional aspects of deep sea drilling in the southwest Pacific: In Burns, R.E., Andrews, J.E., et al., Initial Reports of the Deep Sea Drilling Project, Volume 21: Washington (U.S. Government Printing Office), p. 897-906.

1973. Initial Reports of the Deep Sea Drilling Project, Volume 21: Washington (U.S. Government Printing Office), p. 369-440.

Davies, H.L. and Smith, I.E., 1971. Geology of eastern Papua: Geol. Soc. Am. Bull., v. 82, p. 3299-3312.

Ewing, J.I., et al., 1970. Sediment distribution in the Coral Sea: Geophys. Res., v. 75, p. 1963-1972.

Falvey, D.A. and Taylor, L.W.H., 1974. Queensland Plateau and Coral Sea Basin: Structural and time stratigraphic patterns: Australian Soc. Explor. Geophys., v. 5, p. 123126. 
Gardner, J.У., 1970. Submarine geology of the western Coral Sea: Geol. Soc. Am. Bull., v. 81, p. 856-881.

Glaessner, M.F., 1950. Geotectonic position of New Guinea: Am. Assoc. Petro. Geol. Bull., v. 34, p. 856-881.

Hayes, D.E. and Ringis, J., 1973. Seafloor spreading in the Tasman Sea: Nature, v. 243, p. 454-458.

Kennett, J.P., Burns, R.E., Andrews, J.E., Chuckin, M., Davies, T.A., Dumitrica, P., Edwards, A.K., Galehouse, T.S., Packham, G.H., and Van der Lingen, G.J., 1972. Australian-Antarctic continental drift, paleocirculation changes and Oligocene deep-sea erosion: Nature Phys. Sci., p. 51-55.
Krause, D.C., 1967. Bathymetry and geologic structure of the northwestern Tasman Sea-Coral Sea-South Solomon Sea area of the Southwestern Pacific Ocean: New Zealand Oceanogr. Inst. Memoir 41.

Taylor, G.R., 1973. Preliminary observations on the structural history of Rennell Island, South Solomon Sea: Geol. Soc. Am. Bull., v. 84, p. 2795-2806.

Winterer, E.L., 1970. Submarine valley systems around the Coral Sea Basin (Australia): Marine Geol., v. 8, p. 229244.

Wiseman, J.D.H. and Ovey, C.D., 1954. Proposed names of features on the seep-sea floor: 1. The Pacific Ocean: DeepSea Res., v. 2, p. 93. 